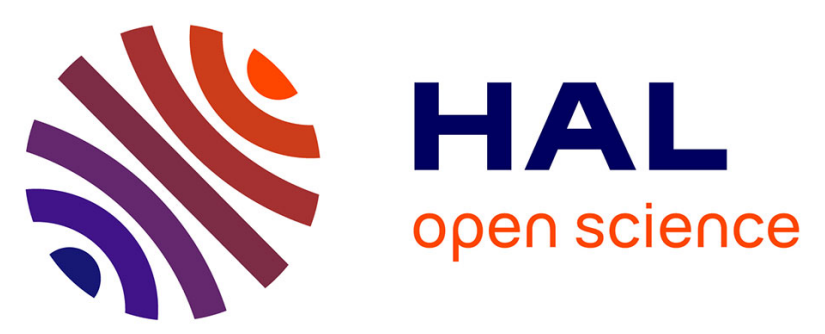

\title{
Occurrence and linkage between secreted insecticidal toxins in natural isolates of Bacillus thuringiensis
}

S. Espinasse, Josette Chaufaux, C. Buisson, Stéphane Perchat, Michel M. Gohar, Denis D. Bourguet, Vincent V. Sanchis Borja

\section{- To cite this version:}

S. Espinasse, Josette Chaufaux, C. Buisson, Stéphane Perchat, Michel M. Gohar, et al.. Occurrence and linkage between secreted insecticidal toxins in natural isolates of Bacillus thuringiensis. Current Microbiology, 2003, 47, pp.501-507. 10.1007/s00284-003-4097-2 . hal-02681218

\section{HAL Id: hal-02681218 \\ https://hal.inrae.fr/hal-02681218}

Submitted on 12 Aug 2020

HAL is a multi-disciplinary open access archive for the deposit and dissemination of scientific research documents, whether they are published or not. The documents may come from teaching and research institutions in France or abroad, or from public or private research centers.
L'archive ouverte pluridisciplinaire HAL, est destinée au dépôt et à la diffusion de documents scientifiques de niveau recherche, publiés ou non, émanant des établissements d'enseignement et de recherche français ou étrangers, des laboratoires publics ou privés. 


\title{
Occurrence and Linkage Between Secreted Insecticidal Toxins in Natural Isolates of Bacillus thuringiensis
}

\author{
Sylvain Espinasse, ${ }^{1}$ Josette Chaufaux, ${ }^{1}$ Christophe Buisson, ${ }^{1}$ Stéphane Perchat,${ }^{1}$ Michel Gohar, ${ }^{1,2}$ Denis Bourguet, ${ }^{1}$ \\ Vincent Sanchis ${ }^{1,3}$ \\ ${ }^{1}$ Unité de Recherches de Lutte Biologique, INRA La Minière, 78285 Guyancourt Cedex, France \\ ${ }^{2}$ Aventis Crop Science, Jozef Plateaustraat 22-B 9000 Ghent, Belgium \\ ${ }^{3}$ Unité de Biochimie Microbienne, Institut Pasteur, 25 rue du Dr. Roux, 75724 Paris Cedex 15, France
}

\begin{abstract}
Little is known about the occurrence and linkage between secreted insecticidal virulence factors in natural populations of Bacillus thuringiensis (Bt). We carried out a survey of $392 \mathrm{Bt}$ strains isolated from various samples originating from 31 countries. The toxicity profile of the culture supernatants of these strains was determined individually against Anthonomus grandis (Coleoptera) and Spodoptera littoralis (Lepidoptera). We analyzed $\beta$-exotoxin I production and searched for the genes encoding Vip1-2, Vip3, and Cry1I toxins in 125 of these strains. Our results showed that these insecticidal toxins were widespread in $B t$ but that their distribution was nonrandom, with significant linkage observed between vip3 and crylI and between vipl-2 and $\beta$-exotoxin I. Strains producing significant amounts of $\beta$-exotoxin I were more frequently isolated from invertebrate samples than from dust, water, soil, or plant samples.
\end{abstract}

Although microbial populations display apparent overall genotypic and phenotypic homogeneity, many microbial species exhibit considerable diversity, which has an impact on the biological properties of individual strains [16]. This is especially important for microorganisms with pathogenic properties, such as Bacillus thuringiensis $(B t)$. Bt, which has a worldwide distribution [19], is a sporogenic bacterium used in biological control that synthesizes specific insecticidal toxins [24]. To date, most studies on $B t$ insecticidal toxins have focused on $\delta$-endotoxins, which are produced as parasporal inclusions, whereas little is known about the pathogenic potential of the compounds secreted into the culture medium $[7,15]$. Many $B t$ strains secrete vegetative insecticidal proteins (Vips) during vegetative growth [27]. Two classes of Vip toxins have been described. The first consists of a binary system composed of two proteins, Vip1 and Vip2, which are $100 \mathrm{kDa}$ and $52 \mathrm{kDa}$ in size, respectively. These proteins are highly toxic to certain coleopteran species $[27,28]$. The second class consists of an $82.5-\mathrm{kDa}$ pro-

Correspondence to: V. Sanchis; email: vsanchis@pasteur.fr tein, Vip3, which is active against a wide spectrum of lepidopteran insects [8]. These two classes of protein do not display sequence homology. Cry1I (also referred as to CryV in the literature) is another insecticidal toxin secreted during early stationary phase. It is active against certain lepidopteran and coleopteran insect larvae [15]. Finally, several $B t$ strains also produce a thermostable exotoxin, known as $\beta$-exotoxin I or thuringiensin [7]. This compound is an adenine nucleotide analogue, highly toxic to a wide range of insect species [9], that is thought to inhibit RNA polymerase [25], thereby affecting insect molting and pupation, in some cases having teratogenic effects [5]. $\beta$-exotoxin $\mathrm{I}$ is also toxic to mammalian cells $[3,18]$ and is very persistent in the environment [4]. It has therefore been banned for public use in accordance with WHO recommendations [29]. If we are to improve the efficacy and ensure safety of $B t$ products, we need to increase our understanding of the genetic variability of natural $B t$ populations with respect to the expression of these secreted virulence factors. In this study, we analyzed the toxicity of culture supernatants of natural Bt isolates to larvae of Spodoptera litto- 
Table 1. Oligonucleotides used in this study

\begin{tabular}{llll}
\hline Primer & \multicolumn{1}{c}{ Sequence } & Description, accession number & Product size (bp) \\
\hline cry1I-fw & $5^{\prime}$ aacactcagtatatgaat 3' & position 1059-1374, L49391 & 378 \\
cry1I-rev & $5^{\prime}$ cacatgtgatgctgaaat 3' & position 1437-1419, L49391 & 378 \\
vip2-fw & $5^{\prime}$ gggaaagaaaagaaaaagagtgg 3' & position 231-255, A64136 & 914 \\
vip2-rev & $5^{\prime}$ catatatccttgtcttctt 3' & position 1145-1124, A64136 & 914 \\
vip3-fw & $5^{\prime}$ acatcctcctacacttctaatac 3' & position 1700-1725, L48811 & 678 \\
vip3-rev & $5^{\prime}$ tcttctatggacccgttctctac 3' & position 2378-2353, L48811 & 678 \\
\hline
\end{tabular}

ralis (Lepidoptera: Noctuidae) and Anthonomus grandis (Coleoptera: Curculionidae). We then explored the genomes of 125 natural $B t$ isolates for the genes encoding the four known insecticidal toxins secreted by $B t$. The prevalence of these toxins in this species was determined and their distribution in relation to sample origin analyzed. We found that the secreted insecticidal toxins were not randomly distributed among $B t$ populations.

\section{Materials and Methods}

Bacterial cultures and supernatant preparation for toxicity assays. The INRA collection contains 1260 natural Bt strains, representing isolates from 101 countries over the world, isolated from various sources (soil, insects, dust, plants, animal waste, etc.). These strains were primarily characterized as $B$. thuringiensis on the basis of their ability to produce crystals during sporogenesis [6]; they are conserved as spores in $12 \% \mathrm{vol} / \mathrm{vol}$ glycerol suspension at $-20^{\circ} \mathrm{C}$. $392 \mathrm{Bt}$ strains, representing isolates from France and from 31 other countries across the five continents, were randomly taken from our collection. The strains were grown on LB nutrient agar plates at $30^{\circ} \mathrm{C}$. Liquid cultures, in $100-\mathrm{mL} \mathrm{LB}$, were inoculated from a single colony and shaken for $24 \mathrm{~h}$ at $30^{\circ} \mathrm{C}$. The cultures were harvested at mid-sporulation (before cell lysis) by centrifugation at $14,000 \mathrm{~g}$ for $10 \mathrm{~min}$ at $4^{\circ} \mathrm{C}$. The supernatants were filtered twice through $0.2-\mu \mathrm{m}$ Nalgene filter units (Nalgene). The resulting extracts, to be used for toxicity assays and $\beta$-exotoxin I determination, were stored at $-20^{\circ} \mathrm{C}$ until bioassay.

Insect bioassays. The toxicity of the $B t$ supernatant preparations was determined using neonate larvae of $S$. littoralis and eggs of A. grandis, using a free ingestion technique. S. littoralis larvae were fed with an artificial diet [21], dispensed into 50 -well plastic plates $\left(1.65-\mathrm{cm}^{2}\right.$ surface each). Supernatant $(25 \mu \mathrm{L})$ was applied uniformly over the food surface and allowed to dry. One neonate larvae was placed on each of 35 wells and incubated for 10 days at $25^{\circ} \mathrm{C}$, with a photoperiod of 16:8 (L:D) hours and 70\% relative humidity (RH). Mortality was recorded at 3, 6, and 10 days. For A. grandis, the supernatant was incorporated into an artificial diet to a final concentration of $8 \%$ and dispensed into sterile 24-well plates. The diet consisted of a mixture of soya flour, cotton flour, wheat germ oil, cholesterol, sugar, vitamins, and agar. One egg of A. grandis was placed on the food in each well. Control larvae developed on untreated food for three weeks after hatching at $25^{\circ} \mathrm{C}$. Percentages of mortality were calculated at three weeks after Abbott correction [1].

PCR amplifications for cry1I, vip3, and vip1-2 detection. The oligonucleotides used in this study are listed in Table 1. The specific primers used to detect the cry1I, vip2, and vip3 genes were designed from the cry1I, vip2, and vip 3 gene sequences present in the databases using Primer Select from the DNAStar software (DNAStar Inc). DNA was obtained from cells grown overnight on LB-agar plates and resuspended in $100 \mu \mathrm{L}$ of distilled water. Cell membranes were disrupted by freezing at $-70^{\circ} \mathrm{C}$ and immersion in a $98^{\circ} \mathrm{C}$ water bath (heat shock). The cells were centrifuged and the DNA suspension $(2 \mu \mathrm{L})$ was mixed with $0.5 \mu \mathrm{L}$ of each primer $(0.1 \mu \mathrm{M}), 0.5 \mathrm{U}$ Taq polymerase, water (50 $\mu \mathrm{L}), \mathrm{MgCl}_{2}$, and buffer, according to the manufacturer's instructions (Gibco-BRL). PCR conditions were as follows: denaturation for $5 \mathrm{~min}$ at $94^{\circ} \mathrm{C}$, followed by 35 cycles of $1 \mathrm{~min}$ at $94^{\circ} \mathrm{C}, 1 \mathrm{~min}$ at $50^{\circ} \mathrm{C}, 1 \mathrm{~min}$ and $30 \mathrm{~s}$ at $72^{\circ} \mathrm{C}$, and a final elongation for $10 \mathrm{~min}$ at $72^{\circ} \mathrm{C}$. Amplifications were recorded as positive, only when specific fragments of the expected size were found after migration on a $1 \%$ agarose gel. PCR results were considered to be negative if no amplicon was obtained after two attempts with independent DNA preparations.

Detection and quantification of $\boldsymbol{\beta}$-exotoxin $\mathbf{I}$. $\beta$-exotoxin I was extracted from the culture supernatant by solvent extraction and quantified by HPLC [11]. Briefly, for solvent extraction, acetone was added to the exotoxin in $0.2 \mathrm{~mL}$ of the culture supernatant to a final concentration of $90 \%$, and the mixture was centrifuged. The pellet was resuspended in $0.2 \mathrm{~mL}$ of double distilled (dd) water. Acetonitrile was added to a final concentration of $40 \%$ and the mixture was then centrifuged. The pellet was discarded and the acetonitrile concentration of the supernatant brought up to $90 \%$. The precipitate was collected by centrifugation and the pellet was resuspended in $100 \mu \mathrm{L}$ of $50 \mathrm{mM}$ potassium phosphate buffer, $\mathrm{pH}$ 2.5. For HPLC, we injected $25 \mu \mathrm{L}$ of the sample into a Lichrospher (Merck) C18 endcapped $4-\times 250-\mathrm{mm}$ column. A gradient of $5 \%$ to $15 \%$ methanol in $50 \mathrm{~mm}$ potassium phosphate buffer, $\mathrm{pH} 2.5$ was developed over $10 \mathrm{~min}$. The flow rate was $1 \mathrm{~mL} / \mathrm{min}$, and UV absorption was monitored at $260 \mathrm{~nm}$. $\beta$-exotoxin I was eluted at $5.5 \mathrm{~min}$. The detection limit of this method for $\beta$-exotoxin I was $2 \mu \mathrm{g} / \mathrm{mL}$. A standard sample (70\% purity) of $\beta$-exotoxin I was kindly provided by I. Thiery from the Laboratoire des Bactéries Entomopathogènes (Institut Pasteur, Paris, France).

Statistical analyses. Frequencies of virulence factors. Total frequencies of occurrence for each virulence factor were calculated from the experimental data. Assuming that there was no linkage between the virulence factors, the expected frequencies for each combination of the virulence factors is the product of the frequencies of the presence or of the absence of each virulence factor. For example, let us consider the four virulence factors $\{a, b, c, d\}$ present with frequencies of respectively $\left\{f_{\mathrm{a}}, f_{\mathrm{b}}, f_{\mathrm{c}}, f_{\mathrm{d}}\right\}$. The expected frequency of the combination $(\mathrm{a}, \mathrm{b}$, c) is $\mathrm{F}_{\mathrm{abc}}=f_{a} \cdot f_{b} \cdot f_{c} \cdot\left(1-f_{d}\right)$. Expected frequencies were compared to the observed ones, using the Pearson chi-square test, the null hypothesis being no linkage between the virulence factors. The Pearson correlation coefficient was calculated for each pair of virulence factors. The significance of all the correlations in the matrix was tested with the Bartlett chi-square test, and the probabilities associated with each correlation were corrected for multiple tests using the Bonferroni method [13] 
Table 2. Insecticidal activity of the culture supernatants of natural Bacillus thuringiensis isolates against larvae of Spodoptera littoralis and Anthonomus grandis

\begin{tabular}{|c|c|c|c|c|c|}
\hline \multirow[b]{2}{*}{$\begin{array}{l}\text { Number of } \\
\text { supernatants }\end{array}$} & \multirow[b]{2}{*}{$\begin{array}{l}\text { Mortality } \\
\text { rate }(\%)\end{array}$} & \multicolumn{4}{|c|}{ Number of strains with supernatants toxic to: } \\
\hline & & $\begin{array}{c}\text { Both } \\
\text { S. littoralis } \\
\text { and A. grandis }\end{array}$ & $\begin{array}{l}\text { S. littoralis } \\
\text { only }\end{array}$ & $\begin{array}{l}\text { A. grandis } \\
\text { only }\end{array}$ & Neither species \\
\hline \multirow{2}{*}{$\begin{array}{l}\text { Toxic supernatants } \\
\quad n=180\end{array}$} & $71-100 \%$ & 29 & 107 & 5 & - \\
\hline & $31-70 \%$ & 4 & 32 & 3 & - \\
\hline \multirow{2}{*}{$\begin{array}{l}\text { Nontoxic supernatants } \\
\quad n=212\end{array}$} & $6-30 \%$ & - & - & - & 28 \\
\hline & $0-5 \%$ & - & - & - & 184 \\
\hline Total $n=392$ & - & 33 & 139 & 8 & 212 \\
\hline
\end{tabular}

$n=$ number of $B t$ strains.

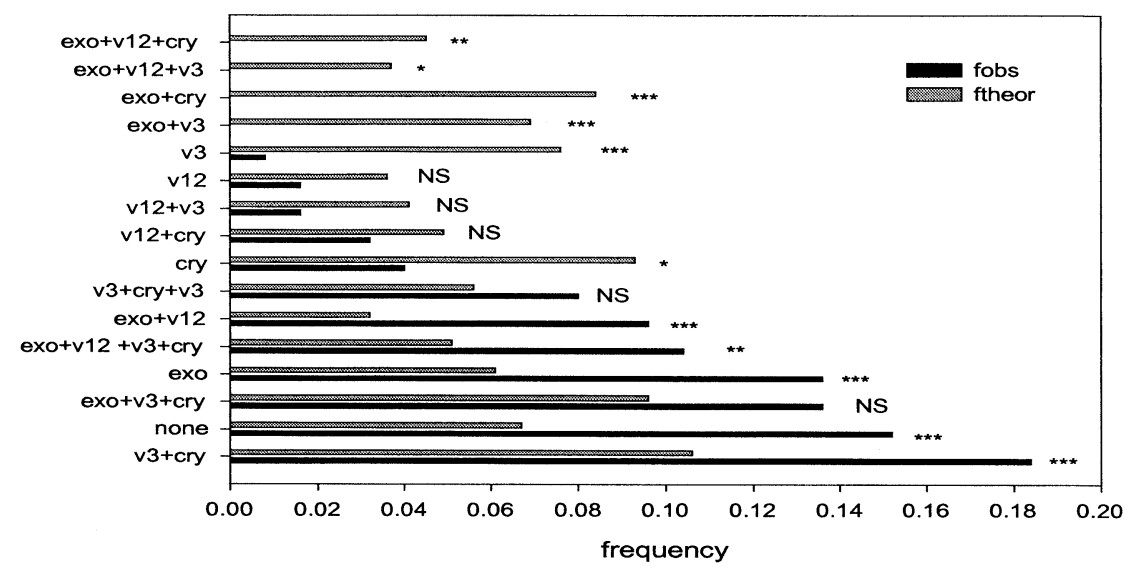

Fig. 1. Chi-square analysis of the linkage between various virulence factors in natural $B t$ isolates $(* p<$ $0.05 ; * * p<0.01 ; * * * p<0.005$; NS: not significantly different; exo, $\beta$-exotoxin I; v12, vip1-2; v3, vip3; cry, cry1I; fobs, frequency observed; ftheor, theoretical frequency).
Relationship between sample or geographic origin and genotypic or toxicity profiles. For each toxicity profile (i.e. nontoxic, toxic only to $S$. littoralis, or toxic only to A. grandis), the homogeneity of the frequencies observed for the different categories in sample or geographic origin were tested using a two-sided Fisher's exact test on contingency tables. Fisher's exact tests were performed using the STRUC program implemented in GENEPOP 3.2a [22].

\section{Results}

Toxicity of stationary-phase culture supernatants of $B t$ isolates to $S$. littoralis and $A$. grandis. We assessed the activity of the culture supernatants of $392 B t$ isolates against larvae of $S$. littoralis and A. grandis (Table 2). Bt isolates were differentiated into four groups: nontoxic, toxic only to $S$. littoralis, toxic only to A. grandis, or toxic to both insects. We found that 212 culture supernatants $(54.1 \%)$ were inactive or only slightly toxic to both insect species ( $0-30 \%$ mortality), 139 were toxic to S. littoralis only, 33 were toxic to both S. littoralis and A. grandis, and the supernatants of eight isolates were toxic only to A. grandis.

Screening of $125 \mathrm{Bt}$ isolates for the presence of $\operatorname{cry} 1 \mathrm{I}$, vip3, and vip1-2 genes and for the production of 及-exotoxin I. We selected 125 isolates for further analysis and investigated whether these toxicity patterns were correlated with the presence of one or several of the four known secreted insecticidal toxins. These strains were representative of the various toxicity profiles observed among the 392 samples initially studied and originated from different locations and sampling sources. The number of samples with each of the four toxicity profiles was representative of the frequency of these profiles in the bioassay. For each strain, we determined the amount of $\beta$-exotoxin I present in the culture supernatant, using an improved quantification method based on reverse-phase HPLC [11]. $\beta$-exotoxin I production $(>2 \mu \mathrm{g} / \mathrm{mL})$ was detected in $47.2 \%$ of the strains. We also used PCR to investigate whether these 125 strains contained the cryll, vip 3 , and vipl-2 genes. The PCR products were of the expected sizes, $378 \mathrm{bp}$ for cryll, $676 \mathrm{bp}$ for vip3, and 914 bp for vip1-2 (Table 3). The cryll gene was detected in $57.6 \%$, vip3 in $52.8 \%$, and vipl-2 in $34.4 \%$ of the 125 strains studied. Fifteen percent of the strains generated no PCR product for the three insecticidal toxin genes examined and produced less than $2 \mu \mathrm{g} / \mathrm{mL} \beta$-exotoxin I. The 45 isolates with supernatants 
Table 3. Detection of cry1I, vip3, and vip1-2 genes by PCR analysis and quantification of $\beta$-exotoxin I in 125 isolates of Bacillus thuringiensis

\begin{tabular}{|c|c|c|c|c|c|c|}
\hline \multirow{2}{*}{$\begin{array}{l}\text { Toxicity profile of } \\
\text { the supernatants }\end{array}$} & \multirow{2}{*}{$\begin{array}{c}\text { Total number } \\
\text { of isolates } \\
\text { examined }\end{array}$} & \multicolumn{3}{|c|}{ Genotype screening by PCR } & \multirow{2}{*}{$\begin{array}{l}\text { Determination of } \beta \text { - } \\
\text { exotoxin I } \mu \mathrm{g} \text { per } \mathrm{mL} \\
\text { of culture supernatant }\end{array}$} & \multirow{2}{*}{$\begin{array}{l}\text { Number } \\
\text { of isolates }\end{array}$} \\
\hline & & cry1I & vip3 & vip1-2 & & \\
\hline \multirow[t]{13}{*}{ Nontoxic } & \multirow[t]{13}{*}{$67(53.6 \%)$} & - & - & - & $0<\mu \mathrm{g}<2$ & 20 \\
\hline & & - & - & - & $2<\mu g<5$ & 14 \\
\hline & & - & - & - & $7 \mu \mathrm{g}$ & 1 \\
\hline & & + & + & - & $0<\mu g<2$ & 8 \\
\hline & & + & + & - & $2<\mu g<5$ & 3 \\
\hline & & + & + & + & $0<\mu g<2$ & 4 \\
\hline & & + & + & + & $2<\mu \mathrm{g}<5$ & 2 \\
\hline & & + & - & + & $0<\mu g<2$ & 5 \\
\hline & & + & - & - & $0<\mu \mathrm{g}<2$ & 4 \\
\hline & & - & + & - & $0<\mu \mathrm{g}<2$ & 1 \\
\hline & & - & - & + & $0<\mu g<2$ & 2 \\
\hline & & - & - & + & $2<\mu \mathrm{g}<5$ & 2 \\
\hline & & - & + & + & $0<\mu \mathrm{g}<2$ & 1 \\
\hline \multirow[t]{5}{*}{ S. littoralis only } & \multirow[t]{5}{*}{$45(36 \%)$} & + & + & - & $0<\mu g<2$ & 15 \\
\hline & & + & + & - & $2<\mu g<5$ & 13 \\
\hline & & + & + & - & $10 \mu \mathrm{g}$ & 1 \\
\hline & & + & + & + & $0<\mu g<2$ & 7 \\
\hline & & + & + & + & $2<\mu g<5$ & 9 \\
\hline A. grandis only & $3(2.4 \%)$ & - & - & + & $15<\mu \mathrm{g}<50$ & 3 \\
\hline \multirow{4}{*}{$\begin{array}{l}\text { S. littoralis and } \\
\text { A. grandis }\end{array}$} & \multirow[t]{4}{*}{$10(8 \%)$} & - & - & - & $>50 \mu \mathrm{g}$ & 1 \\
\hline & & + & + & + & $>50 \mu \mathrm{g}$ & 1 \\
\hline & & - & + & - & $0<\mu g<2$ & 1 \\
\hline & & - & - & + & $>50 \mu \mathrm{g}$ & 7 \\
\hline Total & 125 & 72 & 66 & 43 & $57^{*}$ & 125 \\
\hline
\end{tabular}

$*>2 \mu \mathrm{g}$ of $\beta$-exotoxin $\mathrm{I} / \mathrm{mL}$.

toxic to $S$. littoralis harbored both the vip3 and crylI genes, the products of which are known to be active against certain lepidopteran insects but not against coleopterans [8], and produced small amounts of $\beta$-exotoxin I $(<5 \mu \mathrm{g} / \mathrm{mL})$. Twelve of the 13 isolates toxic to $A$. grandis produced significantly larger amounts of $\beta$-exotoxin I ( $>5 \mu \mathrm{g} / \mathrm{mL})$ and harbored vip $1-2$ genes. Three of these isolates were toxic to A. grandis $(100 \%$ mortality in all cases) but not to $S$. littoralis ( $<15 \%$ mortality). We determined precisely the $\mathrm{LC}_{50}$ of purified $\beta$-exotoxin I for both insects and found that $A$. grandis was five times more susceptible than $S$. littoralis to this toxin $\left(\mathrm{LC}_{50} \mathrm{~s}\right.$ of $6 \mu \mathrm{g} / \mathrm{mL}$ and of $30 \mu \mathrm{g} / \mathrm{mL}$, respectively). The three strains toxic to $A$. grandis only produced intermediate amounts of $\beta$-exotoxin I $(\sim 16-50 \mu \mathrm{g} / \mathrm{mL})$, consistent with the observed pattern of mortality. Nine of the 10 isolates toxic to both insects produced more than 50 $\mu \mathrm{g} / \mathrm{mL} \beta$-exotoxin I, accounting for their activity against both species. We found only one isolate toxic to $A$. grandis that did not produce $\beta$-exotoxin I or possess vip1-2 genes. This particular isolate contained a vip3like gene whose expression product was not toxic to $A$. grandis. This suggests that this strain secretes another, possibly novel, type of insecticidal compound highly active against $A$. grandis and/or S. littoralis.
Statistical analysis of toxicity and genotype data. The observed frequencies of the various genotypes among the $125 \mathrm{Bt}$ strains were compared to the expected frequencies of the 16 possible genotypes in the absence of linkage among these four factors (the toxin genes and $\beta$-exotoxin I production). We observed an overall significant difference $(p<0.0001)$ between the observed and expected frequencies, indicating linkage disequilibrium between the virulence factors. The sample only contained representatives of twelve of the sixteen possible genotypes (Fig. 1, black bars) and seven of them accounted for most of the variability. For all but two of these categories (vip3 + crylI $+\beta$-exotoxin I and vip3 + crylI + vipl-2), the deviations of the observed frequencies from the expected frequencies was significant $(p<0.01)$. These linkages-i.e., vip3 + crylI $(23$ strains), none of the parameters examined (19 isolates), $\beta$-exotoxin I ( $>2 \mu \mathrm{g} / \mathrm{mL}$ ) (17 isolates), all four toxins (13 isolates), and vip $1-2$ and $\beta$-exotoxin I (12 isolates) resulted in the frequencies of the most represented of the secreted virulence factors (i.e., Cry1I and Vip3), present singly in a strain, being much lower $(p<0.05$ and $p<$ 0.005 for crylI and vip3, respectively) than expected. Similarly, the frequency of $\beta$-exotoxin I production in strains with vip3 or crylI genes was also lower than 
expected $(p<0.005)$. The other combinations were also underrepresented in the population. We used pairwise correlation analysis to investigate this differentiation further (Fig. 2). We found that there was a positive correlation between the vip3 and crylI genes $(r=0.81, p<$ $0.001)$ and between the presence of vip $1-2$ and $\beta$-exotoxin I production $(r=0.3, p=0.002)$. This is consistent with our finding that toxicity to $S$. littoralis was almost always associated with the presence of vip 3 and crylI and that toxicity to $A$. grandis was associated with the presence of vipl-2 and $\beta$-exotoxin I production. Conversely, we found that $\beta$-exotoxin I production was negatively correlated with the presence of vip3 $(r=$ $-0.24, p<0.05)$ and with the presence of crylI in a given strain $(r=-0.28, p<0.01)$. We also analyzed the frequency of the various toxicity profiles as a function of the geographic origin or nature of the samples. The toxicity profile was not dependent $(p>0.05)$ on the geographic origin (Europe, Asia, Africa, or America) or the nature of the sample (invertebrates, dust, water, soil, or plants). However, strains producing more than $5 \mu \mathrm{g}$ of $\beta$-exotoxin I were preferentially isolated from invertebrates (this difference being marginally significant: $p=$ $0.05)$.

\section{Discussion}

In this study, we investigated the prevalence and distribution of various insecticidal compounds, secreted by $B t$, to obtain an insight into the biological diversity of natural isolates. Analysis of the toxicity spectra of the culture supernatants of the $392 \mathrm{Bt}$ isolates revealed that over half the strains were not toxic to $S$. littoralis and $A$. grandis. This suggests that a large number of isolates do not secrete insecticidal compounds (at the concentrations tested) or that they produce toxic compounds active against other insect species. Among the toxic isolates those with activity against $S$. littoralis were the most frequent in this screening, consistent with previous observations that active $B t$ strains are generally more prevalent among lepidopteran species [6, 14], the larvae of which are commonly found on leaves of many plants [26].

Analysis of $\beta$-exotoxin I production and search for the genes encoding the secreted Vip1-2, Vip3, and Cry1I toxins in 125 of these isolates indicated that these four toxins are widely distributed among natural $B t$ populations. The vip3 genes were detected in more than $50 \%$ of the strains tested; this figure was much higher than the $23 \%$ reported for the 125 colonies examined by Rice [23], and this difference was highly significant (twotailed Fisher's exact test, $p<10^{-5}$ ). Similarly, we found that $57 \%$ of the strains contained a copy of cryll,

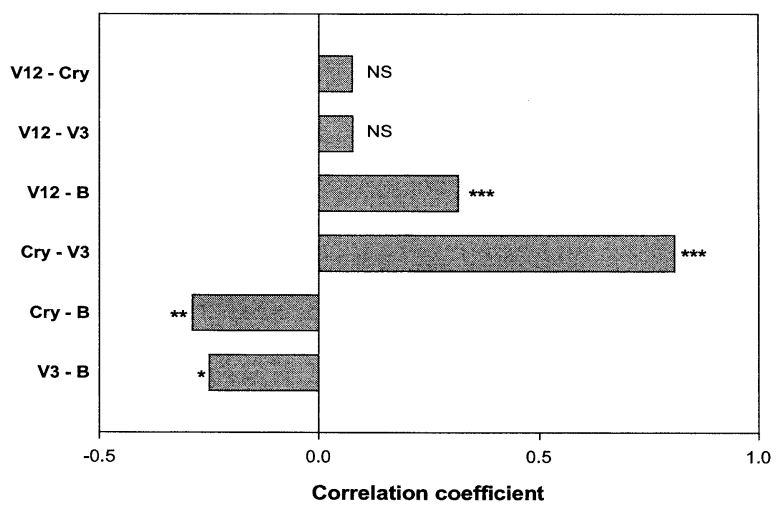

Fig. 2. Pairwise correlations between virulence factors in natural $B t$ isolates $(* p<0.05 ; * * p<0.01$; ***p $<0.005$; NS, not significantly different; B, $\beta$-exotoxin I; v12, vip1-2; v3, vip3; cry, cry1I).

whereas Gleave et al. [10] found that the crylI gene was present in 7 of $21(31 \%) B t$ serotypes, a frequency also significantly lower than that obtained in this study (twotailed Fisher's exact test, $p=0.003$ ). The reasons for these discrepancies are unclear, but may reflect natural variation in bacterial population structures from different locations. On the other hand, the frequency of $\beta$-exotoxin I production reported here, in $47.2 \%$ of the strains, although lower than the 59\% (17 of 29 isolates) reported by Perani et al. [20], is not significantly different (twotailed Fisher's exact test, $p=0.307$ ). Finally, we found that $34.5 \%$ of the isolates contained vip1-2 genes indicating that Vip1-2 toxins are also common among $B t$ strains. Given the large number of natural isolates producing one or several of these toxins, it is likely that these compounds make a significant contribution towards determining the insecticidal host range of individual $B t$ strains. Our results also indicated that the toxicity pattern of the isolates was independent of the nature of the sample (soil, insect, or other sources) and of its geographic origin. This is not very surprising since the ecology and environmental distribution of spore forming bacteria is probably largely due to aerial dispersion. However, we found a fairly good correlation between the genotypic profiles of the isolates and their insecticidal properties. It is therefore possible that some combinations of toxin genes of which the host can take a particular advantage may have become fixed. None of the 67 nontoxic strains produced significant amounts of $\beta$-exotoxin I, and the majority of them neither contained vip3, crylI, or vip1-2. Similarly, all of the isolates toxic to A. grandis produced more than $5 \mu \mathrm{g}$ of $\beta$-exotoxin $\mathrm{I}$, and the production of this compound in most of these strains was associated with the presence of vipl-2 genes. This suggests that toxicity to $A$. grandis is associated mainly with the production of $\beta$-exotoxin I but that both toxins 
may play an important role for virulence against $A$. grandis. We also found that all of the isolates toxic only to $S$. littoralis, harbored both vip3 and crylI. It is not known whether the vip genes are present on the chromosome or on plasmids, but some of the genetic determinants involved in $\beta$-exotoxin I production have been shown to be present on the same plasmids as certain cry genes [12, 17]. We found a strong linkage between vip1-2 and the genetic determinants of $\beta$-exotoxin I, on one hand, and between the crylI and vip3 genes, on the other hand. This provides indirect evidence that the genes encoding these four insecticidal toxins are located on plasmids. We therefore suggest that vip1-2 and the genetic determinants of $\beta$-exotoxin I are generally present on the same plasmid and that crylI and vip3 are generally present on another plasmid. The evolution and dissemination of adaptative traits such as toxin production in bacterial populations is frequently mediated by DNA elements such as plasmids [2]. One possible driving force and mechanism responsible for the genetic shaping and divergence of natural $B t$ populations could be the transfer and fixation of advantageous plasmid/ toxin genes combinations that allow a given strain to become established as a new clonal population and colonize a special niche. However, further research is needed to establish whether there is indeed a correlation between the genetic differentiation of $B t$ populations and the presence of certain plasmid types or specific plasmidborne toxin genes combinations.

\section{ACKNOWLEDGMENTS}

We thank Didier Lereclus, in whose laboratory this work was conducted. We also thank Alex Edelman and Associates for editing the English manuscript. This work was supported by the Institut Pasteur and the Institut National de la Recherche Agronomique (INRA). We would like to thank Sophie Fleurdépine for technical assistance with PCR. Jeroen Van Rie is acknowledged for the gift of the primers used for PCR. Sylvain Espinasse was supported by a grant from Aventis Crop Science, Ghent, Belgium.

\section{Literature Cited}

1. Abbott WS (1925) A method for computing the effectiveness of an insecticide. J Econ Entomol 18:265-267

2. Arber W (2000) Genetic variation: Molecular mechanisms and impact on microbial evolution. FEMS Microbiol Rev 24:1-7

3. Beebee T, Korner A, Bond RP (1972) Differential inhibition of mammalian ribonucleic acid polymerases by an exotoxin from Bacillus thuringiensis. The direct observation of nucleoplasmic ribonucleic acid polymerase activity in intact nuclei. Biochem $\mathrm{J}$ 127:619-634

4. Benz G (1966) On the chemical nature of the heat stable exotoxin of Bacillus thuringiensis. Experientia 22:81-82

5. Burgerjon A, Biache G, Cals P (1969) Teratology of the Colorado potato beetle, Leptinotarsa decemlineata, as provoked by larval administration of the thermostable toxin of Bacillus thuringiensis. J Invertebr Pathol 14:274-278
6. Chaufaux J, Marchal M, Gilois N, Jehanno I, Buisson C (1997) Research on natural strains of Bacillus thuringiensis in different biotopes throughout the world. Can J Microbiol 43:337-343

7. De Barjac H, Dedonder R (1965) Isolation of an identifiable nucleotide from the thermostable toxin of Bacillus thuringiensis var Berliner. C R Acad Sci Paris 260:7050-7053

8. Estruch JJ, Warren GW, Mullins MA, Nye GJ, Craig JA, Koziel MG (1996) Vip3A, a novel Bacillus thuringiensis vegetative insecticidal protein with a wide spectrum of activities against lepidopteran insects. Proc Natl Acad Sci USA 93:5389-5394

9. Farkas J, Sebesta K, Horska K, Samek Z, Dollijs J, Storm F (1969) The structure of exotoxin of Bacillus thuringiensis var. gelechiae. Coll Czech Chem Com 34:1118-1120

10. Gleave AP, Williams R, Hedges R.J (1993) Screening by polymerase chain-reaction of Bacillus thuringiensis serotypes for the presence of $c r y V$-like insecticidal protein genes and characterization of a cryV gene cloned from Bacillus thuringiensis subsp kurstaki. Appl Environ Microbiol 59:1683-1687

11. Gohar M, Perchat, S (2001) Sample preparation for beta-Exotoxin determination in Bacillus thuringiensis cultures by reversed-phase high-performance liquid chromatography. Anal Biochem 298:112117

12. Gonzalez JM, Brown BJ, Carlton BC (1982) Transfer of Bacillus thuringiensis plasmids coding for delta-endotoxin among strains of B. thuringiensis and B. cereus. Proc Natl Acad Sci USA 79:69516955

13. Holm S (1979) A simple sequentially rejective multiple test procedure. Scand J Statist 6:65-70

14. Iriarte J, Bel Y, Ferrandis MD, Andrew R, Murillo J, Ferré J, Caballero P (1998) Environmental distribution and diversity of Bacillus thuringiensis in Spain. System Appl Microbiol 21:97-106

15. Kostichka K, Warren GW, Mullins, M, Mullins AD, Craig JA, Koziel MG, Estruch JJ (1996) Cloning of a cryV-type insecticidal protein gene from Bacillus thuringiensis: The cryV-encoded protein is expressedearly in stationary phase. J Bact 178:2141-2144

16. Lan R, Reeves PR (2000) Intraspecies variation in bacterial genomes: The need for a species genome concept. Trends Microbiol 8:396-401

17. Levinson BL, Kasyan KJ, Chiu SS, Currier TC, Gonzalez JM (1990) Identification of beta-exotoxin production, plasmids encoding beta-exotoxin and a new exotoxin in Bacillus thuringiensis by using high-performance liquid-chromatography. J Bacteriol 172: 3172-3179

18. Mackedonski VV, Nikolaev N, Sebesta K, Hadjiolov AA (1972) Inhibition of ribonucleic acid biosynthesis in mice liver by the exotoxin of Bacillus thuringiensis. Biochim Biophys Acta 272: $56-66$

19. Martin PAW, Travers RS (1989). Worldwide abundance and distribution of Bacillus thuringiensis isolates. Appl Environ Microbiol 55:2437-2442

20. Perani M, Bishop AH, Vaid A (1998) Prevalence of beta-exotoxin, diarrhoeal toxin and specific delta-endotoxin in natural isolates of Bacillus thuringiensis. FEMS Microbiol Letters 160:55-60

21. Poitout S, Bues R (1970) Elevage de plusieurs espèces de Lépidoptères Noctuidae sur milieu artificiel riche et sur milieu artificiel simplifié. Ann Zool Ecol Anim 2:79-91

22. Raymond M, Rousset F (1995) GENEPOP (version 1.2): Population genetics software for exact tests and ecumenicism. J Hered $86: 248-249$

23. Rice WC (1999) Specific primers for the detection of vip3A insecticidal gene within a Bacillus thuringiensis collection. Lett Appl Microbiol 28:378-382 
24. Schnepf E, Crickmore N, Van Rie J, Lereclus D, Baum J, Feitelson J, Zeigler DR, Dean DH (1998) Bacillus thuringiensis and its pesticidal crystal proteins. Microbiol Mol Biol Rev 62:775-806

25. Sebesta K, Horska K, Vankova J (1970) Mechanism of inhibition of DNA-dependent RNA polymerase by exotoxin of Bacillus thuringiensis. Biochim Biophys Acta 209:357-367

26. Smith RA, Couche GA (1991) The phylloplane as a source of Bacillus thuringiensis variants. Appl Environ Microb 57:311-315

27. Warren GW (1997) Vegetative insecticidal proteins: Novel pro- teins for control of corn pests. In: Carozzi N, Koziel M (eds) Advances in insect control: The role of transgenic plants. London, UK: Taylor and Francis Ltd., pp 109-121

28. Warren GW, Koziel MG, Mullins MA (1998) Auxiliary proteins for enhancing the insecticidal activity of pesticidal proteins. Novartis, US patent 5770696

29. WHO (1999) Guidelines specification for bacterial larvicides for public health use. In: WHO/CDS/CPC/WHOPES/99.2 (ed) Report of the WHO informal consultation, 28-30 April 1999. Geneva: World Health Organization 